\title{
Exploring ESL learners' blended learning experiences and its' effectiveness through web-based technologies
}

\author{
Sangeeth Ramalingam ${ }^{1}$, Melor Md Yunus ${ }^{2}$, Harwati Hashim \\ ${ }^{1}$ Kolej Poly Tech MARA, Bangi, Malaysia \\ ${ }^{1,2,3}$ Faculty of Education, Universiti Kebangsaan Malaysia, Malaysia
}

\section{Article Info \\ Article history: \\ Received Jan 12, 2021 \\ Revised Aug 27, 2021 \\ Accepted Sep 14, 2021}

\section{Keywords:}

21 st century pedagogy

21st century skills

Blended learning

ESL learners

Language learning

Technology

\begin{abstract}
The inability to gain employment among the Malaysian graduates became a critical issue due to lack of 21 st century skills. Higher learning institutions are urged to play their significant roles in producing graduates who have subject knowledge and relevant 21 st century skills. There are many teaching strategies which are currently in practice at tertiary institutions, however more efficient approach is needed to produce well-balanced graduates. This present research proposed a promising approach which is blended learning with web-based technologies to improve students' 21 st century skills. Current literature indicated blended learning has not been sufficiently explored in English as Second Language (ESL) context. Thus, this study aimed to explore ESL learners' blended learning experiences using innovative web-based technologies and to examine the effectiveness of the blended learning strategy in improving the learners' 21st-century skills. Qualitative data were collected through phone call interviews with the participants and analyzed through thematic analysis. Working with a sample of bachelor degree students at a tertiary institution revealed the participants' blended learning experience exceptionally improved their 21 st-century skills in various ways. The result of this study contributes to the pedagogical aspects of ESL teaching and learning and the improvement of 21 st century skills among the students.
\end{abstract}

This is an open access article under the CC BY-SA license.

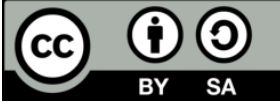

\section{Corresponding Author:}

Melor Md Yunus

Department of Education

National University of Malaysia

43600 UKM, Bangi, Malaysia

Email: melor@ukm.edu.my

\section{INTRODUCTION}

In recent decades, world governments recognized the unemployment issue, especially among graduates. Unemployment among graduates is a serious issue in most nations, including Malaysia. Substantial evidence indicates that long-term unemployment may considerably contribute to global economic development and employment prospects. Although numerous reasons may explain the issue of unemployment among graduates, previous studies [1], [2] revealed lack of 21 st century skills as one of the most significant factors for this phenomenon. Employment possibilities depend on graduates' academic achievements as well as future-ready skills, which can be attained through suitable teaching and learning strategies in tertiary institutions.

Previous researches [1], [3], [4] in international and national contexts observed the lack of 21st century skills among graduates. Such studies indicated that a gap exists between the skills learned in higherlearning institutions and those used in organizations. Moreover, previous researchers [5], [6] revealed a gap 
between skills attained in educational programmes and those utilized in the workplace among graduates. In a study in the Indonesian context, Hadiyanto, et al. [7] found that graduates are not well equipped with 21st century skills.

Studies conducted in the local context supported the statement that graduates lack 21 st century skills. Puad [8] conducted a survey to investigate the point of views of employers, teachers and recent graduates on the factors influencing the difficulties encountered by graduates in finding work and identified lack of 21 st century skills as one of the problems leading to unemployment among recent graduates. Specifically, 21st century skills are attributes and future-ready skills that graduates must possess to perform efficiently in the workplace to become an asset to the development of their organization. Higher-learning institutions should equip graduates with not only adequate knowledge on academic subjects but also 21 st century skills required by industries [9]. Pazilah and Hashim [10] mentioned that graduates must be able to demonstrate soft skills required by industries once they start working. Previous study [11] supported the aforementioned statement by expressing that students graduating from tertiary institutions must possess jobrelated skills, and Rafiq and Hashim [12] emphasized a similar idea.

Examining Malaysian tertiary students' perception of the incorporation of soft skills into the curriculum, Adnan, et al. [13] suggested the modification of teaching and learning approaches to successfully integrate such skills into the curriculum. Currently, numerous teachings and learning approaches in $21 \mathrm{st}$ century education are employed in tertiary institutions. Higher-learning institutions are presently implementing various teaching and learning strategies to promote 21 st century skills in the English as a second language context, such as problem-based learning and asynchronous communication [14], [15]. However, one size does not fit all. Certain strategies may not be suitable for all Malaysian tertiary institutions. Therefore, this study proposes the implementation of blended learning with innovative and modern web-based technologies in tertiary institutions to promote 21 st century skills in students. As technology integration is emphasized in the Malaysian Education Blueprint 2015-2025, increasing numbers of tertiary institutions considered employing blended learning in teaching and learning pedagogy. The learning management system is commonly used to facilitate the implementation of blended learning by Malaysian tertiary institutions. However, the use of modern and innovative web-based technologies together with the learning management system can further enhance students' communication, critical thinking, collaboration and creativity (4C's). Besides, blended learning is seen as a very promising strategy in smart learning environments, especially when it integrates innovative and web-based technologies, such as open educational resources and online software programmes or applications, in face-to-face learning.

Students' learning experiences are crucial in examining the efficiency of blended learning practice in tertiary institutions. Numerous studies on students' blended learning experiences were conducted in various geographical settings, such as Hong Kong, Tehran, New Zealand, Australia, Pakistan, UAE and Singapore [16]-[21]. Such studies focused on different fields of study, such as nursing, health and foreign language. However, students' blended learning experiences in the English as Second Language (ESL) context have yet to be explored sufficiently. Therefore, this study explores ESL learners' experiences in blended learning with innovative web-based technologies and examines the effectiveness of blended learning in improving the learners' 21 st century skills. Meaningful qualitative input from learners can contribute to the pedagogical aspects of teaching and learning 21st century skills in the ESL context.

\section{LITERATURE REVIEW}

Owing to rapid technological changes in the workforce, graduates are encouraged to equip themselves with 21 st century skills to be able to compete with other workers. Several frameworks were introduced to identify core skills areas or specific 21 st century skills that future graduates should develop. Partnership for $21 \mathrm{st}$ century skills recommended certain guidelines for identifying main skills areas. Although several frameworks were proposed, some skills categories are similar to 21 st century skills, such as learning and innovation, information, media and technology and life and career skills [22]. Students in higher-learning institutions should strive to enhance their 21 st century skills, especially the $4 \mathrm{C}$ 's, to complete at the global level.

In the field of English language teaching, educators' perceptions are related to the enhancement of 21st century teaching and learning approaches [23] for equipping students with subject knowledge and relevant soft skills required by organizations. A huge shift can be seen in teaching approaches with the emergence of social constructivism in the 1970s [15]. Learner-centered approaches replaced teacher-centered methods, in which students construct meaning and knowledge on their own based on information and their experiences.

This study is guided by social constructivism [24]. Therefore, blended learning with innovative web-based technologies is used as an active learning approach to align well with 21 st century ESL 
classrooms. As many higher-learning institutions embarked on the use of technology in the classroom, blended learning has become one of the most commonly implemented approaches in 21 st century education. Nevertheless, selecting a suitable blended learning model for implementation is important for highereducation institutions. Selection of the appropriate model can ensure the successful implementation of blended learning in tertiary institutions. Bryan and Volchenkova [25] identified various types of blended learning models, such as the face-to-face model, rotation model and others. The integration of face-to-face and online models can provide numerous benefits to students. The implementation of blended learning in the classroom can promote learners' engagement [26] and enhance their language skills, such as writing, reading, listening and speaking [23]-[27].

Various studies examined the effectiveness of blended learning in improving students' 21 st century skills in different contexts and revealed that blended learning implementation has a positive impact on learners' 21 st century skills. The use of web-based technologies in blended learning classrooms was proven to help students enhance their collaboration, critical-thinking and communication skills [28], [29]. Shamsuddin and Kaur [30] found that the use of ICT tools can create a satisfactory learning environment and enhance students' learning experiences. Web-based tools are useful for boosting students' enthusiasm and motivation in the learning process. The use of Edmodo in blended learning classrooms is extremely effective in promoting student engagement [31]. Nasution, Harahap, and Manurung [32] reported that students' critical-thinking skills for plant tissue cultures improved considerably through the use of blended learning compared with traditional approaches. Nevertheless, Borglum [33] expressed disagreement by arguing that technology may not inevitably improve critical-thinking skills despite its wide used. Rathakrishnan, Ahmad, and Suan [34] examined the use of Padlet online discussions to promote critical thinking and revealed that the use of Padlet online discussion backchannel communication can improve students' critical-thinking level. Apart from critical-thinking and communication skills, evidence showed that the implementation of blended learning can improve other 21 st century skills, such as collaboration and creativity.

Previous studies [35]-[37] focused on different fields of study and applied quantitative approaches. Thus, the present study emphasizes the ESL context and employs a qualitative approach, as it aims to investigate learners' experiences in blended learning with innovative web-based technologies. In addition, this empirical research is conceptualized and operationalized based on the following precepts: i) What are ESL learners' experiences in the implementation of blended learning with innovative web-based technologies?; and ii) How effective is the implementation of blended learning in improving the 21 st century skills of the ESL learners based on their experiences?

\section{RESEARCH METHOD}

The objective of this study was to explore ESL learners' experiences in the implementation of blended learning with innovative web-based technologies and investigate the effectiveness of blended learning in improving the ESL learners' 21 st century skills. As this study focused on leaners' blended learning experiences and how they make sense of such experiences, a qualitative research design was employed. This approach is useful for understanding the participants' experiences in certain phenomena based on their behaviors and culture [38], [39].

\subsection{Sample subject and size}

For qualitative studies, choosing participants who can provide valuable information is important. Merriam [39] stressed that selected participants for qualitative studies must have attributes that reflect the purpose in order to provide rich information on the phenomenon under investigation. Based on the purposive sampling criterion, five final-year undergraduate accounting students were selected for this study. The finalyear students were chosen from a tertiary institution and had at least five semesters of learning in a blended learning environment. Therefore, the five students were suitable participants for sharing their purposeful experiences in blended learning. Sampling adequacy was achieved based on data saturation. The researchers did not interview additional participants, as sufficient information was gathered to achieve the objectives of the study [40]. The participants' anonymity was ensured, and the researchers identified the students as P1, P2, P3, P4, and P5 to keep their identities confidential.

\subsection{Research instruments and procedures}

As this study was purely qualitative, the data collection instrument used was semi-structured interviews. The researchers designed an interview protocol to serve as guidelines for conducting the interviews. Telephone semi-structured interviews were conducted to obtain meaningful input on the participants' experiences in blended learning with innovative web-based technologies and the effectiveness of blended learning in enhancing their 21 st century skills. The semi-structured interviews involved 
predesigned open-ended questions prepared by the researchers. Although open-ended questions were prepared before the interview sessions, several new questions emerged during the conversations between the researchers and participants. The telephone interviews were transcribed verbatim and saved as Word files. The interview transcriptions were transferred to NVivo 12 for data management and organization.

\subsection{Validity and reliability}

Strategies for ensuring the validity and reliability of qualitative studies include explaining and describing a situation and interpreting the data to minimize errors [41]. The participants were informed about the purpose of the study before the interview sessions to reduce errors. The validity and reliability of the interview questions were improved by asking the questions repeatedly and getting feedback or responses from the participants. The interview sessions were audio recorded after permission was obtained from the participants. Subsequently, the interviews were transcribed and saved as text documents. Member checking or respondent validation was conducted to ensure the validity of the research data [40]. Interview transcriptions were emailed to the participants, who were instructed to confirm their responses before the data analysis process. The validity of the data was also confirmed by checking whether the data were in line with the research scope and questions [39].

\subsection{Data analysis}

The six-stage thematic analysis (TA) method developed by Braun and Clarke was used to analyze the qualitative data [42] and NVivo 12 was employed to manage, organize and display the findings from the interview sessions. The steps of the Braun and Clarke's TA method involve getting familiarize with data, producing initial codes, identifying for themes, reviewing and checking potential themes, specifying the names of themes and finally writing the report.

In addition to Braun and Clarke [42], suggestions from Krippendorff [43] were considered during the results analysis. The findings underwent a winnowing process, as a code-based approach was employed in this study, in which only relevant statements in the interview transcripts were selected as codes, with several analytical strategies such as reducing the information, identifying the codes and displaying the data.

\section{RESULTS}

The findings on the themes derived from the code identification through thematic distinction, as suggested by previous studies [39], are presented in this section, followed by a discussion on the overall results of the study. The findings of the research are presented in response to the research questions. Several themes and subthemes were derived after the code identification process. However, only the main themes related to the research questions are discussed in detail.

The student participants valued their experiences and perceived the implementation of blended learning with innovative web-based technologies as beneficial. The utilization of web-based technologies in blended learning ESL classrooms was deemed as a promising teaching and learning strategy for enhancing the learners' 21 st century skills. Excerpts from the interviews are presented to support and justify the findings in the discussion.

\subsection{Theme I: Positive experiences}

Research question 1: What are ESL learners' experiences in the implementation of blended learning with innovative web-based technologies?

The blended learning experiences of the ESL participants were expressed through the benefits they gained, their feelings, and the challenges they encountered in classrooms employing blended learning with various innovative web-based technologies. Most of the participants stated that they had positive experiences in blended learning activities, as such it helped them become independent and engaged, stay focused, and explore new ways of learning. Moreover, the innovative applications and websites enabled the participants to gain easy access to materials and motivated them to be active in the learning process and flexible.

\footnotetext{
"Blended learning encouraged me to learn independently." (P3)

"Blended learning can engage me in the learning process." (P1)

"Blended learning helped me stay focused." (P3)

"Blended learning helped me discover new learning apps and websites." (P5)

"It encouraged me to explore new things." (P4)

"Blended learning attracted my interest. I can also access other information to gain knowledge." (P2)
} 
"After the class ended, I can refer to my notes or watch the videos recorded by my lecturer. I can have flexible time for myself." (P3)

When the participants were requested to share their feelings towards participating in web-based blended learning activities, they revealed similar emotions. All the participants expressed positive emotions when discussing their feelings. The participants shared that joining blended learning activities was enjoyable, exciting, fun and interesting.

"I enjoyed blended learning so much.” (P1)

"I get excited when lecturers combine both face-to-face methods with online methods." (P2)

"But when the lecturer blends the methods, it is different." (P4)

"Learning becomes more fun." (P3)

"It is more fun." (P5)

The interviews revealed that most of the participants had positive feelings towards and gained various benefits from joining different blended learning activities utilizing web-based technologies. Nevertheless, the participants expressed dissatisfaction when asked about the challenges they encountered in blended learning classrooms. The two most common challenges mentioned by the participants were Internet connection issues and excessive use of data. Although they were excited to participate in blended learning activities, the two issues were major concerns.

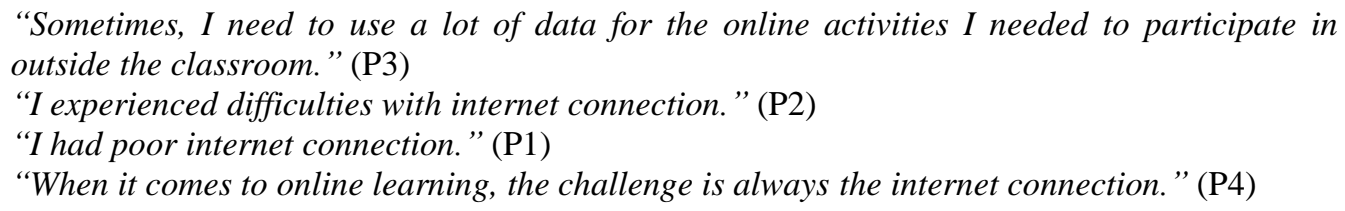

\subsection{Theme II: 21st Century skills}

Research question 2: How effective is the implementation of blended learning in improving the 21st century skills of the ESL learners based on their experiences?

Employers expect graduates to have not only adequate knowledge but also job-related skills to be able to contribute to the development of the organization. Equally emphasizing the skills needed by $21 \mathrm{st}$ century employees and the knowledge acquired by graduates is crucial for higher-learning institutions when developing relevant curricula [44]. Various types of 21 st century skills are important for graduates to work in different industries. Specifically, 21st century skills include communication skills, problem-solving skills, decision-making skills, critical-thinking skills, leadership skills, information management skills and so on. Based on the explanation provided by the participants, the improvement of soft skills was one of the benefits they gained from their blended learning experiences. The general opinions of the participants involved in blended learning and the 4C's of 21 st century skills are presented.

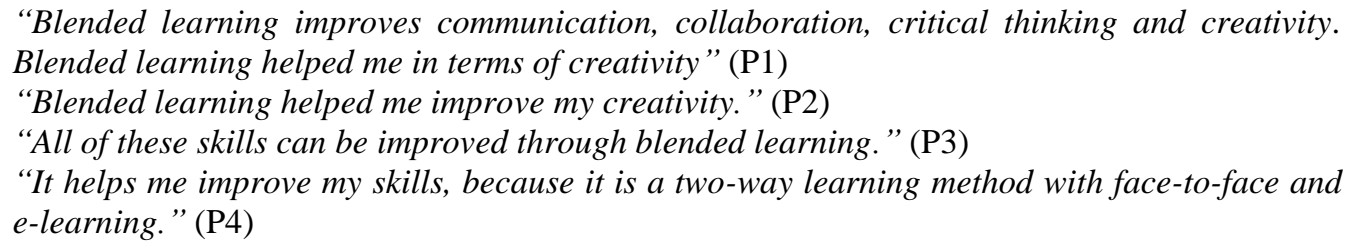

The participants explained their web-based blended learning experiences in many ways. Most of the participants revealed their blended learning experiences by explaining their feelings and emotions during the blended learning activities as well as the benefits they gained from such activities. Based on the interviews, involvement in blended learning activities helped the participants improve their future-ready skills needed in various industries. Improving students' skills with conventional approaches or online learning alone may be difficult. As blended learning integrates both conventional and non-conventional learning, the participants expressed that both approaches were effective in helping them develop their skills.

\subsubsection{Blended learning encourages collaborative activities}

The participants felt that involvement in blended learning activities encouraged collaboration with classmates and therefore helped improve their collaboration skills. Most of the participants stated that when collaborating with friends, they could listen to others' points of view and share their opinions, thoughts, and 
views at the same time. Other participants pointed out that blended learning activities enabled them to collaborate with their classmates to answer problem-based questions. One of the participants said that working in teams allowed her to gather information and improve the learning process.

"It helped me collaborate with my classmates during the learning process, because there is a platform like WhatsApp group, wherein everyone can give their own opinions and ideas, and then we can discuss them." (P1)

“... Discussion in which we are free to discuss and state our opinions. ” (P2)

"We work together to solve the questions, and during the discussion, we exchange ideas and come up with a solution to solve especially tricky questions. It is more practical to solve a problem or task when working together with classmates." (P3)

"Teamwork is the best way to gather information and improve the learning process." (P4)

"Online classes can be held in groups, in which students and lecturers can be there together and be engaged." (P5)

Nevertheless, one of the participants felt that online collaboration was sometimes troublesome. When questioned about her opinion, she said that sometimes, poor internet connection was an obstacle to having discussions with classmates. Hence, she preferred collaboration activities in a face-to-face environment.

"I experienced slight difficulties in working together during the online learning process, because not all my classmates had good Internet connection. I prefer to sit together and have face-to-face discussions, so that we can discuss and solve any problem at that time." (P2)

\subsubsection{Blended learning promotes communicative activities}

The participants revealed that their experiences in blended learning with web-based technologies provided opportunities to become involved in communication activities and enhance their speaking skills. The students who were interviewed for this study agreed that blended learning helped improve their communication skills, as they were required to participate in face-to-face and online communication activities, such as making presentations and joining discussions. One of the participants believes that blended learning enables students who are less active in face-to-face classrooms to communicate and contribute ideas in online learning platforms. Another participant explained that studying in blended learning classrooms can help improve not only students' speaking skills but also social aspects or their characteristics.

"So, blended learning helped my speaking skills, as I needed to communicate in both ways." (P4)

"Blended learning helped my speaking skills by allowing me to communicate through an online platform. I was free to chat, share my thoughts and support my friends." (P2)

"Blended learning involves face-to-face interactions in the classroom and thus students have the chance to enhance their speaking skills. When it comes to online classes, it allows students who are shy to convey their opinions, to speak and improve their speaking skills." (P5)

"It could improve the social aspects of students." (P1)

In certain instances, the participants felt that the use of creative web-based technologies with their lecturers during face-to-face and online learning improved their speaking skills. The participants expressed that innovative web-based blended learning enhanced their speaking skills to respond or provide feedback to their lecturers, ask questions to clarify a task or topic and so on.

"Through blended learning, I can improve my speaking skills by asking questions and sharing some ideas with my friends." (P1)

"Online learning somehow helps when I want to ask questions about a topic I do not understand." (P3)

"As for online learning, I can also ask anything to my lecturer through a communication medium, such as WhatsApp and Telegram.” (P4)

\subsubsection{Blended learning fosters creativity}

From the interviews, it was determined that the participants' blended learning experiences helped them develop their creativity. One of the participants stated that lecturers' implementation of blended learning with various web-based technologies assisted the students in exploring new concepts and sharing 
their innovative ideas with others. Most of the students shared their experiences in using various software and tools to create posters and edit videos and emphasized that such methods were how blended learning made them innovative.

"I can give innovative ideas to others, like editing video. I can express my ideas and innovation by editing pictures, posters and videos using Canva." (P1)

"We had to use our creativity to create a poster. So, we had to conduct research on the Internet and find various tools and apps like Canva and Microsoft Publisher to make the poster. That was how blended learning helped in terms of creativity. " (P2)

"It encouraged me to explore new things." (P3)

"Blended learning helps me to be creative and innovative in everything I do." (P4)

"The abundant information on the Internet will encourage students to be more creative and innovative. For instance, in video making, there are lots of software for students to learn how to create a video." (P5)

\subsubsection{Blended learning cultivates critical thinking}

The participants revealed that critical thinking was another 21 st century skill they developed from their web-based blended learning experiences. Critical-thinking skills require students to analyze, interpret and evaluate information. Many of the participants shared that they obtained opportunities to improve their critical- thinking skills by joining problem-solving activities. In problem-solving tasks, the students were able to think critically, formulate arguments and solve problems or issues. One of the participants mentioned that completing assignments using different types of web applications helped boost her critical-thinking skills.
"When the lecturer gives a problem to solve, I'll think critically and give my argument and opinion to solve it." (P1)
"We have to use our critical-thinking skills to answer questions. This type of learning helped me analyze, understand and give arguments. " (P2)
"Critical thinking involves tasks on how to interpret, analyze and evaluate information. For me, I managed to boost my critical thinking and develop all these abilities through assignments." (P3)
"Blended learning helped me think critically and analyze and interpret a problem, because it is a two-way method that can open up and widen an idea. It does improve my critical-thinking skills, because as we know, not all the information provided on the Internet is appropriate. Critical thinking helps me choose the right information for my course." (P4)

\section{DISCUSSION}

The first research question in this study was formulated to examine ESL learners' experiences in the implementation of blended learning with various web-based technologies. Overall, the majority of the participants had positive feelings towards web-based blended learning technologies. All the participants expressed having positive experiences based on three aspects, that is, the benefits they gained, their feelings and the challenges they encountered, in their involvement in blended learning activities with various interesting web-based applications. Most of the participants expressed positive emotions towards participating in blended activities in the classroom. The participants also shared the different types of blended learning activities they joined. The activities mentioned by the participants include communication activities, teamwork activities, group discussions, problem-solving tasks, presentations, poster making and video making using various online tools and other media. The positive experiences expressed by the participants could stem from their perception of the usefulness and ease of use of the web-based technologies [45]. In this digital age, students are relatively comfortable with using modern technologies and tools, which can increase their perceived ease of use.

The second research question was formulated to investigate the efficacy of web-based blended learning in improving the 21 st century skills of the ESL students based on their experiences. The findings revealed that active involvement in different web-based blended learning activities helped the participants develop the 4C's. This outcome is evident in previous study [46], wherein the developed blended learning model enhanced the learning of 21 st century skills. Most of the participants seemed to have similar opinions on how blended learning helped enhance their 21 st century skills. Nevertheless, the existence of several challenges in implementing blended learning in the classroom cannot be denied. The most common issue in blended learning implementation was poor Internet connection, as identified by one of the participants during the interviews. 
However, the majority of the participants strongly agreed that the various web-based blended learning activities improved their soft skills. This finding is promising, as many educators perceive developing 21 st century skills in students a challenging task [47]. Involvement in blended learning tasks enabled the participants to develop such skills, as blended learning combines face-to-face and online learning and therefore gives students opportunities to enhance their 21 st century skills. The participants emphasized the benefits they gained from face-to-face and various web-based technologies, which assisted them in enhancing their 21 st century skills. The findings from previous study [48] presented a similar idea. This outcome was also supported by Lalima and Dangwal [49], as their findings stated that blended learning plays a huge role in equipping students with all the skills they would need in various industries. Such students are Generation $\mathrm{Z}$ students, who are hands-on and participate actively in the learning process.

Many findings from previous studies supported those of the present study [50]. The results of previous research indicated the positive impact of the implementation of blended learning on the development of 21st century skills, especially communication skills. Tawil [51] found that the use of blended learning can considerably improve students' speaking skills. Studies conducted in 2018 and 2019 [52], [53] also obtained similar findings. Some findings from previous studies revealed how blended learning implementation can develop other 21st century skills. Rusli and Hashim [54] determined that the integration of blended learning-enabled team-based settings in classrooms. Furthermore, Wahab, et al. [55] proved that skills such as problem solving and critical thinking can be improved in learners through the use of the 21Emerging Literacy \& Language Assessment (ELLA) online tool. The researchers of the present study hope that the gap between the 21st century skills learned in higher-learning institutions and skills needed by organizations can be reduced through the implementation of innovative web-based blended learning technologies in ESL classrooms.

\section{CONCLUSION}

This study aimed to explore ESL learners' experiences in web-based blended learning and the effectiveness of the strategy in improving their 21 st century skills. Overall, it was observed that the majority of the participants had extremely positive experiences in and perceptions of the implementation of blended learning with additional modern and innovative web-based technologies and tools. Usefulness and perceived ease of use played a significant role in the students' positive experiences in the innovative web-based blended learning and teaching strategy. In terms of the effectiveness of blended learning integrating modern webbased applications and tools, the participants valued their experiences and viewed web-based blended learning as an efficient strategy for enhancing their 21 st century skills, particularly the 4C's. The research findings clearly indicated that web-based blended learning assisted the ESL learners in improving their 21st century skills despite the challenges they encountered when participating in virtual learning and practices.

The qualitative findings of this study could be beneficial to English curriculum developers and instructors for improving and extending current blended learning pedagogical strategies, particularly in ESL classrooms. The input from the participants could be helpful to curriculum developers and instructors in choosing the right and relevant web-based technologies for ESL teaching and learning as well as the teaching of skills necessary for 21 st century learning. Educators must recognize suitable pedagogical strategies that can encourage students' active engagement and help enhance their 21 st century skills. Thus, educators should develop teaching and learning activities that integrate 21 st century skills in learners. The utilization and application of modern web-based technologies in blended learning classrooms can create another level of dimension in ESL which the implication of it could develop the development of 21 st century skills in learners.

However, this study was conducted in only one higher-learning institution and focused on a qualitative research method. Future studies can focus on the different learning environments of various institutions by employing quantitative and qualitative methods to further determine the effectiveness of webbased blended learning strategies. As blended learning demonstrates considerable potential in education, future studies may also focus on the effectiveness of web-based blended learning approaches for other $21 \mathrm{st}$ century skills apart from the 4C's.

\section{REFERENCES}

[1] J. Nadarajah, "Measuring the gap in employability skills among Malaysian graduates," Int. J. Mod. Trends Soc. Sci., vol. 4, no. 15, pp. 81-87, 2021, doi: 10.35631/IJMTSS.415007.

[2] F. Puteh-Behak, et al., "Enhancing The Quality of Life Using Multiliteracies Project Approach to Augment Employability Skills Among Malaysian University Graduates,” J. Islam. Soc. Sci. Humanit., vol. 20, no. 1, pp. 96-106, 2019, doi: 10.33102/abqari.vol20no2.207. 
[3] M. Abelha, S. Fernandes, D. Mesquita, F. Seabra, and A. T. Ferreira-Oliveira, "Graduate Employability and Competence Development in Higher Education-A Systematic Literature Review Using PRISMA," Sustainability, vol. 12 , no. 15 , p. 5900, 2020, doi: 10.3390/su12155900.

[4] N. Fajaryati, B. Budiyono, M. Akhyar, and W. Wiranto, "The employability skills needed to face the demands of work in the future: Systematic literature reviews," Open Engineering, vol. 10, no. 1, pp. 595-603, 2020, doi: 10.1515/eng-2020-0072.

[5] M. Sarkar, T. Overton, C. Thompson, and G. Rayner, "Graduate Employability: Views of Recent Science Graduates and Employers," Int. J. Innov. Sci. Math. Educ., vol. 24, no. 3, pp. 31-48, 2016.

[6] R. Prinsley and K. Baranyai, "STEM Skills in the Workforce: What Do Employers Want?" Occasional Paper Series, no. 9, 2015, doi: 10.13140/RG.2.2.12120.60167.

[7] H. Hadiyanto, et al., "Graduate Candidates' 21st Century Skills and Challenge for the Faculty and the University in Online Learning Era University in Online Learning Era," The Turkish Online Journal of Educational Technology, Special issue for IETC\&ITEC, pp. 201-216, 2018.

[8] M. H. Puad, "Obstacles to employability skills training programs in Malaysia from the perspectives of employers', educators' and graduates' perspective,” Int. J. Acad. Res. Bus. Soc. Sci., vol. 8, no. 10, pp. 952-972, 2018, doi: 10.6007/ijarbss/v8-i10/4792.

[9] S. N. Hiong, "Adoption of 21st century skills in teaching and learning," J. Penyelid. IPGKBL, vol. 14, pp. 1-16, 2017.

[10] F. N. Pazilah and H. Hashim, "Using infographics as a technology-based tool to develop 21st century skills in an ESL context," J. Educ. Learn. Stud., vol. 1, no. 1, pp. 35-38, 2018, doi: 10.32698/0242.

[11] M. Md Yunus, H. U. Hashim, and H. Hashim, "Massive Open Online Courses : En Route to Communication Skills Acquisition," Arab World English J., Special Issue CALL, no. 5, pp. 98-109, 2019, doi: 10.24093/awej/call5.8.

[12] K. R. M. Rafiq and H. Hashim, "Augmented Reality Game (ARG), 21st century skills and ESL classroom," J. Educ. Learn. Stud., vol. 1, no. 1, pp. 29-34, 2018, doi: 10.32698/0232.

[13] A. H. M. Adnan, S. Ramalingam, N. Ilias, and T. M. Tahir, "Acquiring and Practicing Soft Skills: A Survey of Technical-technological Undergraduates at a Malaysian Tertiary Institution," Procedia - Soc. Behav. Sci., vol. 123, pp. 82-89, 2014, doi: 10.1016/j.sbspro.2014.01.1400.

[14] I. E.-N. Abdel Wahed Shaalan, "Integrating Project-Based Learning Strategies in the Design of an ESP Dental Vocabulary Course for ESL Malaysian Majors," Arab World English J., vol. 11, no. 3, pp. 464-483, 2020, doi: 10.24093/awej/vol11no3.29.

[15] P. Jamali and M. Krish, "Fostering 21 st century skills using an online discussion forum in an english for specific purpose course," Malaysian J. Learn. Instr., vol. 18, no. 1, pp. 219-240, 2021, doi: 10.32890/mjli2021.18.1.9.

[16] J. Y. C. Lam, "Examining student experience of blended learning from the perspective of the community of inquiry framework," Asian Assoc. Open Univ. J., vol. 10, no. 2, pp. 81-99, 2015, doi: 10.1108/aaouj-10-02-2015-b007.

[17] A. E. Sigaroudi, S. Ghiyasvandian, and A. N. Nasabadi, "Understanding doctoral nursing students' experiences of blended learning: A qualitative study," Acta Med. Iran., vol. 54, no. 11, pp. 743-749, 2016.

[18] K. Tuapawa, "Interpreting experiences of students using online technologies to interact with content in blended tertiary environments: A phenomenological study," Int. J. Distance Educ. Technol., vol. 15, no. 3, pp. 86-103, 2017, doi: 10.4018/IJDET.2017070106.

[19] S. H. Cassum, S. Allana, and J. Dias, "Experiences of adopting blended pedagogies in health assessment course in post RN Baccalaureate Program of nursing in Karachi, Pakistan," J. Educ. Train. Stud., vol. 4, no. 1, pp. 221-228, 2015, doi: 10.11114/jets.v4i1.1168.

[20] J. Moussa-Inaty, "Student experiences of a blended learning environment," Int. J. Learn. Teach. Educ. Res., vol. 16, no. 9, pp. 60-72, 2017, doi: 10.26803/ijlter.16.9.5.

[21] S. Shorey, A. L. Siew, and E. Ang, "Experiences of nursing undergraduates on a redesigned blended communication module: A descriptive qualitative study," Nurse Educ. Today, vol. 61, pp. 77-82, 2018.

[22] Partnership for 21st Century Learning, "P21 Framework Definitions," pp. 1-9, 2009. [Online]. Available: https://files.eric.ed.gov/fulltext/ED519462.pdf.

[23] R. Shadiev and M. Yang, "Review of Studies on Technology-Enhanced Language Learning and Teaching," Sustainability, vol. 12, no. 2, pp. 1-22, 2020, doi: 10.3390/su12020524.

[24] L. Vygotsky, Mind in Society:The Development of Higher Psychological Process. Cambridge: Harvard University Press, 1978.

[25] A. Bryan and K. N. Volchenkova, "Blended Learning: Definition, Models, Implications for Higher Education," Bull. South Ural State Univ. Ser., vol. 8, no. 2, pp. 24-30, 2016, doi: 10.14529/ped160204.

[26] D. Adams, M. H. J. Tan, and B. Sumintono, "Students' readiness for blended learning in a leading Malaysian private higher education institution," Interact. Technol. Smart Educ., 2020, doi: 10.1108/ITSE-03-2020-0032.

[27] H. Hashim, M. Md Yunus, and M. Amin Embi, "Factors influencing polytechnic English as Second Language (ESL) learners' attitude and intention for using mobile learning," Asian ESP J., vol. 14, no. 7, pp. 195-208, 2018.

[28] E. D. T. Puspitasari, H. D. Surjono, and A. D. Minghat, "Utilizing web based learning as 21 st century learning media for vocational education," Int. J. Eng. Technol., vol. 7, no. 4, pp. 157-160, 2018, doi: 10.14419/ijet.v7i4.33.23522.

[29] N. Peachey, Digital Tools for Teachers. Peachey Publications, 2019.

[30] N. Shamsuddin and J. Kaur, "Students' learning style and its effect on blended learning, does it matter?" International Journal of Evaluation and Research in Education (IJERE), vol. 9, no. 1, pp. 195-202, 2020, doi: 10.11591/ijere.v9i1.20422. 
[31] R. Sefriani, R. Sepriana, I. Wijaya, P. Radyuli, and M. Menrisal, "Blended learning with Edmodo: The effectiveness of statixtical learning during the COVID-19 pandemic," International Journal of Evaluation and Research in Education (IJERE), vol. 10, no. 1, pp. 293-299, 2021, doi: 10.11591/ijere.v10i1.20826.

[32] N. E. A. Nasution, F. Harahap, and B. Manurung, "The effect of blended learning on student's critical thinking skills in plant tissue culture course," Int. J. Sci. Res., vol. 6, no. 11, pp. 1469-1473, 2017.

[33] R. N. Borglum, "The effects of blended learning on critical thinking in a high school Earth Science class," M.S. Thesis, Univeristy of Northern Iowa, 2016.

[34] M. Rathakrishnan, R. Ahmad, and C. L. Suan, "Online discussion: Enhancing students' critical thinking skills," AIP Conf. Proc., vol. 1891, no. 1, 2017, doi: 10.1063/1.5005453.

[35] M. Furnes, K. Kvaal and S. Høye, "Communication in mental health nursing - Bachelor Students' appraisal of a blended learning training programme - An exploratory study," BMC Nurs., vol. 17, no. 1, pp. 1-10, 2018, doi: 10.1186/s12912-018-0288-9.

[36] Teoh Joo Tong and Chong Geeng Ling, "Students' Challenges in the Mandarin Classroom : A Blended Learning Experience," Journal of Creative Practices in Language Learning and Teaching, vol. 6, no. 1, pp. 44-55, 2018.

[37] D. Adams, M. T. H. Joo, B. Sumintono, and S. P. Oh, "Blended learning engagement in higher education institutions: A differential item functioning analysis of students' backgrounds," Malaysian J. Learn. Instr., vol. 17, no. 1 , pp. $133-158,2020$.

[38] J. W. Creswell, Qualitative Inquiry and Research Design: Choosing Among Five Approaches, 2nd Ed. California: Sage Publications, 2007.

[39] S. B. Merriam, Qualitative Research: A Guide to Design and Implementation, 2nd Ed. USA: Jossey-Bass, 2009.

[40] J. M. Morse, M. Barrett, M. Mayan, K. Olson, and J. Spiers, "Verification Strategies for Establishing Reliability and Validity in Qualitative Research," Int. J. Qual. Methods, vol. 1, no. 2, pp. 13-22, 2002, doi: $10.1177 / 160940690200100202$.

[41] J. A. Maxwell, The SAGE Handbook of Applied Social Research Methods, 3rd Ed. L. Bickman and D. J. Rog, Eds. SAGE Publications, 2009.

[42] V. Braun and V. Clarke, "Using thematic analysis in psychology, Qualitative Research in Psychology," J. Chem. Inf. Model., vol. 3, no. 2, pp. 77-101, 2006, doi: 10.1191/1478088706qp063oa.

[43] K. Krippendorff, Content Analysis: An Introduction to its Methodology. California: SAGE Publications, 2004.

[44] Z. W. Abas, "Fostering learning in the 21 st century through student engagement," Int. J. Educ. Media Technol., vol. 9, no. 1, pp. 3-15, 2015.

[45] F. Bouilheres, L. T. V. H. Le, S. McDonald, C. Nkhoma, and L. Jandug-Montera, "Defining student learning experience through blended learning," Educ. Inf. Technol., vol. 25, no. 4, pp. 3049-3069, 2020, doi: 10.1007/s10639-020-10100-y.

[46] N. Chaiyama, "The development of blended learning management model in developing information literacy skills (BL-ILS Model)," Int. J. Inf. Educ. Technol., vol. 5, no. 7, pp. 483-489, 2015, doi: 10.7763/ijiet.2015.v5.554

[47] R. S. Malik, "Educational Challenges in 21St Century and Sustainable Development," J. Sustain. Dev. Educ. Res., vol. 2, no. 1, p. 9, 2018, doi: 10.17509/jsder.v2i1.12266.

[48] H. T. Yeen-Ju, N. Mai, and B. Selvaretnam, "Enhancing Problem-Solving Skills in an Authentic Blended Learning Environment: A Malaysian Context," Int. J. Inf. Educ. Technol., vol. 5, no. 11, pp. 841-846, 2015, doi: 10.7763/ijiet.2015.v5.623.

[49] Lalima and K. L. Dangwal, "Blended Learning: An Innovative Approach," Univers. J. Educ. Res., vol. 5, no. 1, pp. 129-136, 2017, doi: 10.13189/ujer.2017.050116.

[50] N. E. M. Said, M. Yunus, L. K. Doring, A. Asmi, F. Aqilah, and L. K. S. Li, "Blogging to enhance writing skills: A survey of students' perception and attitude," Asian Soc. Sci., vol. 9, no. 16, pp. 95-101, 2013, doi: 10.5539/ass.v9n16p95.

[51] H. Tawil, "The Blended Learning Approach and Its Application in Language Teaching," Int. J. Lang. Linguist., vol. 5, no. 4, pp. 47-58, 2018, doi: 10.30845/ijll.v5n4p6.

[52] N. F. B. Hassan, S. Puteh, and A. M. Sanusi "Elements of Technology Enabled/Enhanced Active Learning (TEAL) to Enhance Quality and Employability of Bachelor's Students," MATEC Web Conf., vol. 150, 2018, pp. 4-11, doi: $10.1051 /$ matecconf $/ 201815005005$.

[53] V. Cappi et al., "The use of blended learning to improve health professionals' communication skills: A literature review," Acta Biomed., vol. 90, no. 4, pp. 17-24, 2019, doi: 10.23750/abm.v90i4-S.8330.

[54] R. Rusli and H. Hashim, "Implementing an Online Learning Platform in an English as a Second Language Context: Analyses of Blended Courses Issues and Solution,” Int. J. Eng. Technol., vol. 7, no. 4.21, pp. 65-68, 2018, doi: 10.14419/ijet.v7i4.21.21618.

[55] N. Wahab, H. Harun, M. M. Idrus, A. M. Zain, N. D. M. Nazri, and M. M. Yunus, "21st Century English Language Learning Ambiance via Blended Learning Approach (21-ELLA)," in Proceedings of The International University Carnival on E-Learning (IUCEL), 2018, pp. 494-496. 